Article

\title{
Exploring the Interaction Effects of Board Meetings on Information Disclosure and Financial Performance in Public Listed Companies
}

\author{
Noor Azuddin Yakob ${ }^{1, *(D)}$ and Norraidah Abu Hasan ${ }^{2}$ (D) \\ 1 Graduate School of Business, Universiti Kebangsaan Malaysia, Bangi 43600, Malaysia \\ 2 Faculty of Administrative Science \& Policy Studies, Universiti Teknologi MARA, Seremban 70300, Malaysia; \\ norraidah@uitm.edu.my \\ * Correspondence: azuddin@ukm.edu.my
}

Citation: Yakob, Noor Azuddin, and Norraidah Abu Hasan. 2021.

Exploring the Interaction Effects of Board Meetings on Information Disclosure and Financial Performance in Public Listed Companies.

Economies 9: 139. https://doi.org/ 10.3390/economies 9040139

Academic Editor: Burcin Yurtoglu

Received: 10 August 2021

Accepted: 23 September 2021

Published: 28 September 2021

Publisher's Note: MDPI stays neutral with regard to jurisdictional claims in published maps and institutional affiliations.

Copyright: (c) 2021 by the authors. Licensee MDPI, Basel, Switzerland. This article is an open access article distributed under the terms and conditions of the Creative Commons Attribution (CC BY) license (https:// creativecommons.org/licenses/by/ $4.0 /)$.

\begin{abstract}
The board of directors' role is paramount in businesses because it reflects the organisation's ability to earn investor confidence and improve financial performance. This paper aims to examine the relationship between environmental and social (ES) information disclosure and firm financial performance and the interaction effects of board meetings on the relationship between ES and firm performance in Malaysian publicly traded firms from 2013 to 2017. This article contributes to the theoretical foundations of the agency theory as it relates to the corporate governance function. The agency theory framework is used to capture the inherent interrelationships between the board of directors and firm performance. The study's findings indicate that a firm's relationship between ES and financial performance, measured by Tobin $Q$ and return on equity, may be significantly affected by board meetings.
\end{abstract}

Keywords: agency theory; board meeting; environmental and social disclosure; financial performance; GMM

\section{Introduction}

Investors rely on information disclosure in the business world since it depicts the actual firm performance and the return and risk of investment. Fama (1970) emphasised the importance of information in the Efficient Market Hypothesis (EMH), stating that a market is efficient when the stock price reacts instantly to the arrival of new information. As such, adequate disclosure or reporting enables investors to comprehend the precise state of businesses, their associated risks, and the expected return on their investment (Gackowski 2017). Notably, there is a widespread belief among academics that effective disclosure and sound corporate governance result in superior financial performance for businesses (Chung et al. 2015; Ghani et al. 2016).

The East Asian financial crisis of 1997 had a detrimental effect on the Asian countries' performance, including Malaysia. Consequently, numerous studies have been conducted to determine the primary factors contributing to the incident. Scholars believe it may have been caused by corporate governance malpractice and inadequate information disclosure (Rahman and Haniffa 2005).

Internationally, extensive empirical research has been conducted on the relationship between corporate governance disclosure and firm performance (Merton 1986; Che Hat et al. 2008; Kowalewski 2016). Consensus findings indicated that good corporate governance could boost firm value and attract investors to stock markets. Indeed, the purpose of establishing Corporate Governance Codes in various countries is to address the information asymmetry issue between businesses and investors (Han et al. 2014; Maina et al. 2017). However, empirical research concerning board governance influences the relationship between information disclosure and firm performance is limited. Corporate governance is 
frequently discussed in the business community as the primary mechanism for increasing firm transparency and investor confidence. Due to company directors having a direct relationship with the management and shareholders, this study focuses on board meetings as a corporate governance mechanism. As a developing country, Malaysia's economy depends on effective boards for growth and survival.

It is not systematically researched how board meetings affect disclosure practices and firm performance (Kasbun et al. 2016; Allegrini and Greco 2013; Hashim et al. 2014). Numerous studies examined the relationship between information disclosure and firm performance, but most either looked at a single component of disclosures or utilised a limited sample (Botosan 1997; Cooke 1989; Allegrini and Greco 2013). Besides, various empirical studies investigating the relationship between information disclosure and firm performance have produced equivocal and contradictory conclusions. For example, Ghani et al. (2016) observed that information disclosure (risk management and operational information) is positively associated with financial performance in Malaysian publicly traded companies. This finding was comparable to that of Maina et al. (2017), who found a significant association between information disclosure and the performance of Kenya's listed companies. Nevertheless, it was found in the study by Che Hat et al. (2008) that the relationship between corporate governance and firm performance is not mediated by disclosure. Besides, Atan et al. (2016) found no association between economic, social, and governance disclosure and firm financial performance. As a result of the inconsistencies and contradictory findings in the literature, additional studies on new elements of information disclosure and board governance are necessary.

In contrast to earlier studies, the current study has longer research periods to establish the sustainability disclosure effect on a firm's long-term profits. Utilising long-term data can help determine whether sustainability reporting is a worthwhile long-term investment for firms aiming to enhance profitability, rather than a short fix. This study also employs GMM (two-step) estimation to estimate panel data, which is more credible and accurate. Furthermore, this study looks at the agency theory to explain how firms employ ES disclosure to improve the performance of publicly traded companies.

The paper is structured as follows: Section 2 briefly introduces the agency theory and an overview of environmental and social disclosure, board meetings, and firm performance; Section 3 describes the measurements of the study; Section 4 discusses the research data and methodology in detail; Section 5 explains the discussion; Section 6 presents the conclusion.

\section{Literature Review}

\subsection{Theoretical Background}

An agency relationship is a legal contract between the principal and the agent in which the principal transfers the responsibility and authority of managing the business's activities to the agent. It establishes a distinction between ownership and control, remaining the ownership with the principal and the control with the agent (Jensen and Meckling 1976). Agents are equated to managers in the agency theory, while principals are to shareholders.

According to this theory, the separation of ownership and control results in information asymmetry, as managers have more information than shareholders. Additionally, management can manipulate information to act contrary to the best interests of shareholders (Donnelly and Mulcahy 2008).

According to the agency theory, when a principal (shareholder) and an agent (manager) are separated, conflicting relationships, such as information asymmetry and opportunistic behaviour of agents, exist. As a result, it is critical to closely monitor the agent's activities to minimise conflicts, align principal-agent objectives, and maximise shareholder wealth. Additionally, the agency theory explains that effective corporate governance oversight reduces agency conflicts, increases firm transparency, and improves financial performance (Hanh et al. 2018; Hussain et al. 2018). 


\subsection{Environmental and Social Disclosure}

Environmental and social (ES) disclosure is gaining popularity. It has been established that it allows firms to disclose the sustainability incentive reflecting their successful approaches and earns investor confidence. Sustainability disclosure, also known as sustainability reporting, is a kind of corporate social responsibility (CSR) mandating firms to disclose their environmental and social performance to stakeholders. Environmental and social disclosure (ES) has been identified as new investment criteria for analysing shareholder investments. Investors have begun to pay attention to non-financial information as they recognise that sustainability disclosure reporting enables firms to increase transparency and promote mutual engagement with stakeholders. Kasbun et al. (2016) examined the association between sustainability reporting and the financial performance of Malaysian public listed companies. They noted that firms typically believe that disclosing non-financial information is unnecessary and costly; eventually, a focus on sustainability may lead to a loss of competitiveness.

ES has been shown to open new doors for businesses to improve their performance and reputations to reflect their responsibilities to stakeholders. Additionally, sustainability reporting will strengthen the company's competitive position (Norraidah and Azuddin 2018). Bursa Malaysia introduced a new amendment in 2016 mandating the disclosure of non-financial information. Bursa requires companies to include a quality statement regarding the disclosure of non-financial information in their annual report. This metric will assist in providing a reliable and accurate measure of a company's performance and assist investors in making an investment decision (Kasbun et al. 2016). Evaluating a company's performance based on financial data solely is meaningless in the current financial market. Businesses must evaluate their overall performance concerning nonfinancial factors. According to Loh et al. (2016), Malaysia had a relatively low rate of sustainability disclosure when compared to the other four Asian countries. The low level of disclosure may result from a lack of awareness regarding the costs and benefits of sustainability reporting.

There is a growing interest in researching corporate social and environmental disclosure. Sustainability disclosure is a form of corporate social responsibility (CSR) requiring businesses to disclose their economic, environmental, and social performance to stakeholders. It has been shown to provide companies with opportunities to disclose sustainability incentives reflecting successful business strategies and earn investor trust. Its observance became mandatory in 2014 because it enhances a company's positive image and has an undeniable positive impact on financial performance (Kasbun et al. 2016; Chen et al. 2015).

Sustainability investment awareness has increased worldwide, as shareholders consider the companies' sustainability disclosure before determining investment decisions. According to Chen et al. (2015), high performing corporations have more incentives to reveal social performance information to increase their image and publicity. Similarly, Preston and O'bannon (1997) showed a positive relationship between social disclosure and firm financial performance in US Corporations.

Hypothesis 1 (H1). Environmental and social disclosure has a significant effect on firm performance.

\subsection{Board Meeting}

A board meeting is recognised as a significant component of effective corporate governance. According to the agency theory, board meeting frequency may affect firm performance. Increased meeting frequency promotes idea sharing, performance disclosure, and debate to resolve agency problems. Bursa Malaysia Berhad's (2017) report stated that whilst the minimum number of meetings is not prescribed, it would be in the company's best interest for the board to meet regularly (i.e., at least five meetings if not more frequently as circumstances dictate). Furthermore, according to the Malaysian code on 
corporate governance (MCCG), the number of board meetings is not specified, depending on companies' situations.

Prior research has indicated that frequent meetings improve the board member organisation and communication as a part of the governance mechanism (Correia and Lucena 2020; Elamer et al. 2018). Board meetings clarify any ambiguity and establish shared beliefs, expectations, and values, thus improving firm performance and efficiency. Standardisation of knowledge can be accomplished through frequent meetings, providing an opportunity to discuss both strengths and weaknesses affecting the firm's earnings (Nguyen et al. 2021; Correia and Lucena 2020). Amin et al. (2018) argued that regular board meetings signal to stakeholders that the company is underperforming, requiring an outside director to monitor the firms closely. Wang et al. (2020) were pessimistic about the board meeting. As it turns out, their research showed that board meetings have a detrimental effect on firm performance. As a result, firms are hosting more frequent meetings to deal with issues due to low performance. Additionally, effective board meetings typically alert stakeholders to problems or conflicts in the business operation. Due to these divergent views on the nature of board meetings, it appears as though the question of whether board meetings can potentially have a beneficial governance effect on firm success is an open one.

Chou et al. (2013) discovered that board meetings are associated with firm performance because they help the board monitor and supervise its activities while protecting shareholder wealth. Similarly, Vafeas and Theodorou (1998) found an association between board activity and corporate performance, as measured by the frequency of board meetings. However, a study conducted by Azar et al. (2014) found that the frequency of board meetings negatively correlates with financial performance, as measured by Tobin's Q.

Nurulyasmin et al. (2017) used Ordinary Least Square (OLS) regression to determine the association between board meeting frequency and CSR reporting. They found that the frequency of board meetings is not associated with CSR reporting. As a result, this study examines the interaction effect of board meetings and environmental and social disclosure on firm performance, which may help open the black box between information disclosure and firm performance.

Hypothesis 2 (H2). Board meetings enhance the relationship between environmental and social disclosure.

\subsection{Firm Performance}

From a South-East Asian perspective, Buachoom (2018) agreed that having more board meetings impacts firm performance positively. It reflects the high-performing board's preference for more frequent decision-making and consideration sessions. The outcomes of these sessions can be used to control executives' decisions and motivate them to perform to meet the firm's objectives. Al Farooque et al. (2020) also supported this view, stating that regular meeting activity enables the transfer of knowledge and experience for supervision and executive monitoring. Mishra and Kapil (2018) elaborated on the importance of directors' participation and preparation prior to the meeting to address pertinent issues constructively. Additionally, board meetings are more frequent in larger firms, indicating that greater oversight is required to maintain corporate value.

According to Azar et al. (2014), board meetings are a key component of effective corporate governance. The number of board meetings is a critical resource for increasing the board's effectiveness. Additionally, prior research demonstrated a positive correlation between board meetings and firm financial performance (Hanh et al. 2018). Jensen (1993) argued that a board of directors of a high-performing firm rarely encounters conflict.

The board of directors of a business has become increasingly important during crises. As a result, board meetings are critical to a firm's survival and development. When board members meet regularly, they have many opportunities to exchange, discuss, share ideas, and plan firm strategies. Paul (2017) articulated that regularly corporate board meetings achieve higher and better financial results in earnings per share than those not meeting 
regularly. With this context in mind, this study examines the relationship between board meeting frequency and firm performance.

\section{Measurement of Variables}

The measurements of the independent variable and dependent variable are summarised in Table 1.

Table 1. Summary of Variables.

\begin{tabular}{ccc}
\hline Variables & Measurement & Data Source \\
\hline Dependent Variable & $\begin{array}{c}\text { Tobin's Q (market value of } \\
\text { equities plus book value of } \\
\text { liabilities divided by book } \\
\text { value of total assets) and } \\
\text { Return on equity }\end{array}$ & Bloomberg \\
\hline Independent Variable & \multicolumn{2}{c}{ Bloomberg } \\
\hline Environmental and Social Disclosure & $\begin{array}{c}\text { Environmental and Social } \\
\text { Score }\end{array}$ & Annual Report \\
\hline $\begin{array}{c}\text { Moderating Variable } \\
\text { Board Meeting }\end{array}$ & $\begin{array}{l}\text { Number of board meetings } \\
\text { held for the financial year }\end{array}$ & \\
\hline
\end{tabular}

The independent variables (IV) are environmental and social (ES) disclosures, while the dependent variable is firm performance as measured by Tobin's $Q$ and return on equity (ROE). This study employs both accounting-based and market-based measures of financial performance because they have been perceived as indicators of both short-term and long-term corporate financial performance. Furthermore, the board meeting is used to examine whether board meetings enhance the relationship between environmental and social disclosure and firm performance.

\section{Data and Methodology}

This study examines all non-financial firms listed on the main market of Bursa Malaysia between 2013 and 2017. Due to the full adoption of the amended Corporate Governance Code, revised in 2012, 2013 was chosen as the pilot year. The newly amended Code, published in 2017, takes a fresh look at corporate disclosure standards. This study employs quantitative data analysis and numerical representations of empirical findings to identify and explain the evidence. Tobin $Q$ was the dependent variable representing the firm's financial performance, while environmental and social determinants were independent variables. All data were in logarithmic format and sourced from Bloomberg and the annual report.

Due to the dynamic nature of firm financial performance, an empirical analysis using a dynamic panel data model is more appropriate. The central concept underlying the signalling theory is the firm's financial condition, which is subject to frictions, such as the volume of information disclosed and changes in investor confidence as firm financial performance changes. This study allowed financial performance to fluctuate over time due to board governance and share price performance changes.

Baseline Model is as follow:

$$
y_{i t}=\delta y_{i t-1}+\beta_{1} \mathrm{ES}_{i t}
$$

where,

$y=$ natural logarithm of firm financial performance measured by Tobin's $Q$ and Return on Equity (ROE), ES is the natural logarithm of the environmental and social disclosure score. 
This study predicts that companies with a high level of disclosure will result in better financial performance.

Interaction Model is as follow:

Board Meeting (BM) enhances the relationship between environmental and social (ES) disclosure and firm performance.

$$
y_{i t}=\delta y_{i t-1,}+\beta_{1} \mathrm{ES}_{i t}+\beta_{2} \mathrm{BM}_{i t}+\beta_{3}(\mathrm{ES} \times \mathrm{BM})_{i t}
$$

Table 2 shows the ES disclosure data obtained from financial reports of Malaysian listed companies from 2013 to 2017, involving 277 companies. These businesses were from various industries, including consumer staples, consumer discretionary, technology, materials, industrials, communications, healthcare, energy, and utilities.

Table 2. Descriptive Statistic.

\begin{tabular}{|c|c|c|c|c|c|c|}
\hline Variables & Mean & Median & Std. Dev. & Min & Max & Obs \\
\hline \multicolumn{7}{|l|}{ Dependent variable } \\
\hline Tobin Q & 1.60 & 1.05 & 5.740 & 0.30 & 207.02 & 1366 \\
\hline ROE & 8.83 & 7.37 & 30.323 & 105.74 & 369.91 & 1373 \\
\hline $\begin{array}{c}\text { Independent variab } \\
\text { ES } \\
\text { Moderating variab }\end{array}$ & 80.35 & 83.33 & 10.481 & 16.67 & 100.00 & 1290 \\
\hline Board meeting & 5.53 & 5.00 & 1.910 & 1.00 & 27.00 & 1334 \\
\hline
\end{tabular}

The correlation structure of environmental and social disclosure has a positive and substantial association with Tobin's Q, ROA, and ROE, with coefficient values of 0.1061 , 0.1035 , and 0.1181 , respectively, as shown in Table 3. A positive correlation indicates a direct relationship, meaning that increasing environmental and social disclosure increases the firm's ROA, Tobin's Q, and ROE. A high level of disclosure transparency is associated with improved performance.

Table 3. Correlation Matrix (IV: ES Disclosure, DV: Tobin's Q and ROE).

\begin{tabular}{cccccc}
\hline & Tobin Q & ROA & ROE & ES & Board Meeting \\
\hline tobin & 1.00 & & & & \\
roa & $0.3277^{*}$ & 1.00 & & & \\
roe & $0.3087^{*}$ & $0.9195^{*}$ & 1.00 & & \\
es & $0.1061^{*}$ & $0.1035^{*}$ & $0.1181^{*}$ & 1.00 & 1.00 \\
board_m & $-0.0506^{*}$ & $-0.1122^{*}$ & $-0.0608 *$ & $0.0613 *$ & \\
\hline Note: An * indicates statistical significance at the level of $5 \%$ or less.
\end{tabular}

Figure 1 depicts the mean number of board meetings for Malaysian companies in each industry's line chart from 2013 to 2017. From the chart, industries, such as consumer staples, consumer discretionary, technology, and materials, did not experience many changes in the number of board meetings. Next, Malaysian companies from the industrials and healthcare industries had raging changes in the number of board meetings. In general, Malaysian companies from the communications and utility industries experienced an increase in the number of board meetings from 2013 to 2017. On the other hand, companies from the energy industry experienced a decrease in the number of board meetings. Finally, the utility industry had the highest number of board meetings, followed by the communications industry. 


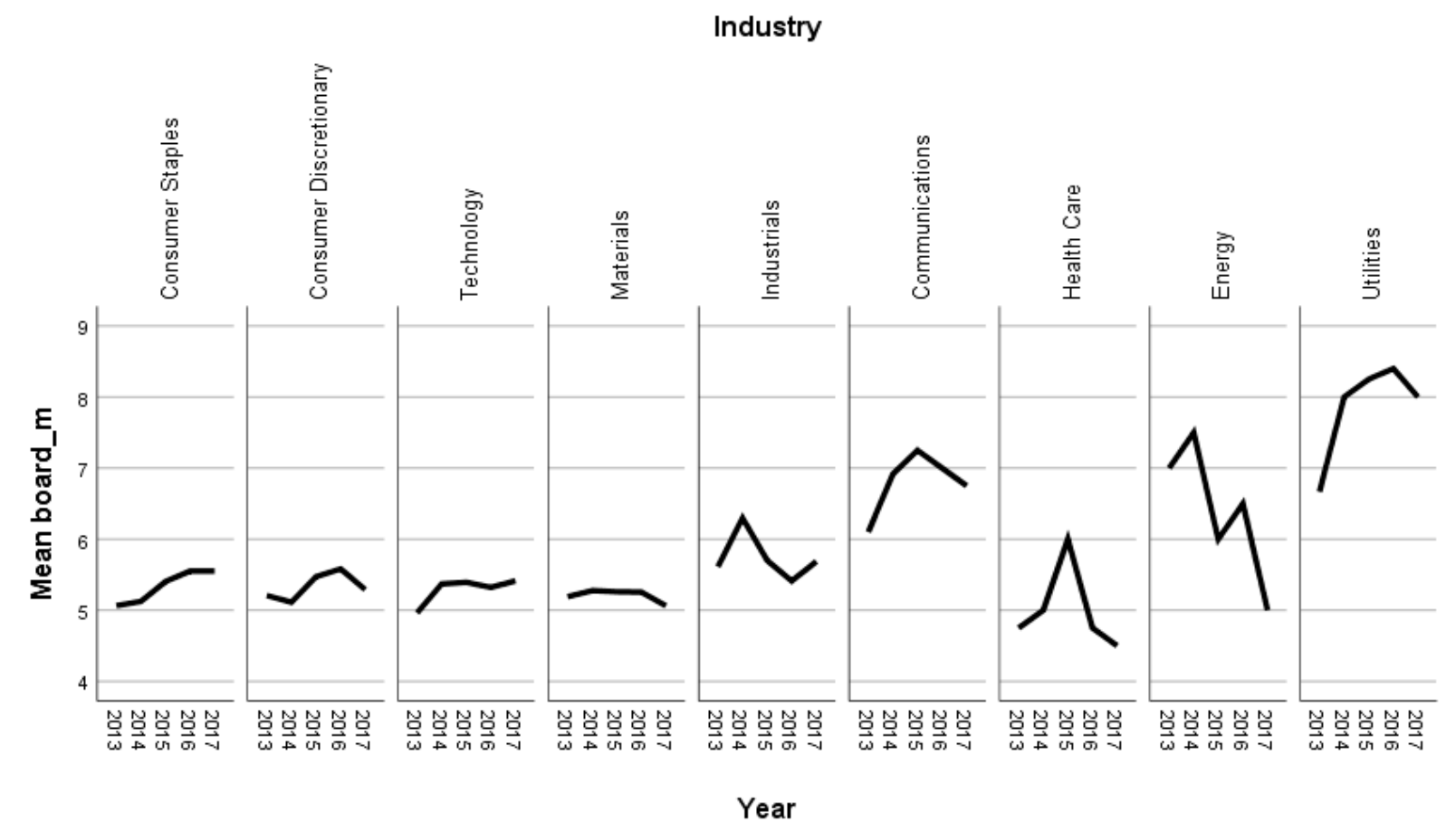

Figure 1. Number of Board Meetings (Mean) by Industries from 2013 to 2017.

This study used the Arellano and Bond (1991) System Generalised Method of Moments (GMM) to ensure the instrument validity and reduce bias and other possible exogenous variables. The GMM's two-step approach recognises the dependent variable's persistence by including its lag value as an explanatory variable in the regression model. Two specification tests were used to evaluate the robustness of the instrument variables used in the GMM system estimations. Hansen and Singleton (1982) introduced the J-statistic, a metric for over-identifying constraints associated with the null hypothesis that the instruments are correct. The $p$-values for the Hansen J-statistic were not statistically significant, indicating that the instruments were valid for all regressions. This study established the validity of treating all regressors as exogenous except for the lagged dependent variable. The second was the Arellano and Bond (1991) autocorrelation test, which ruled out the null hypothesis of no first- and second-order serial association in the model's residuals. AR (1) was present, as estimated by the first-order serial correlation, due to the error terms associated with the lagged dependent variable. While AR (2), the approximate second-order serial correlation coefficient, indicated that all regression models' residuals were devoid of second-order correlations. Model 1, the two-step system GMM result, indicated that ES disclosure has a statistically significant negative correlation with firm performance, as measured by Tobin's $\mathrm{Q}$ (coeff $=-0.410, p=0.1$ ) and ROE (coeff $=-4.748, p=0.1$ ), contradicting Hypothesis 1 .

Model 2 discussed the role of board meetings influencing the relationship between ES and firm performance. Interestingly, the results in Table 4 indicate that the board meeting interaction coefficient is positive and statistically significant compared to Tobin's $Q$ (coeff $=0.156, p=0.1$ ) and ROE (coeff $=0.950, p=0.1$ ). It can be argued that regularly meeting boards encourage management to focus on shareholder value creation and performance enhancement. The significant effect of board meetings on firm performance is consistent with the agency theory's view, indicating that board meeting attendance is significant and is viewed as an indication of the board's successful monitoring activities. The interaction between meetings demonstrates that they positively enhance the relationship between environmental and social disclosure and firm performance, verifying Hypothesis 2. 
Table 4. The relationship of sustainability disclosure and firm financial performance: (Dependent Variable: Tobin Q and ROE).

\begin{tabular}{|c|c|c|c|c|}
\hline \multirow{3}{*}{ Variables } & Model 1a & Model 2a & Model 1b & Model 2b \\
\hline & \multicolumn{2}{|c|}{ System GMM Two-Step } & \multicolumn{2}{|c|}{ System GMM Two-Step } \\
\hline & \multicolumn{2}{|c|}{ Tobin Q } & \multicolumn{2}{|c|}{ ROE } \\
\hline \multirow{2}{*}{ Firm Performance $(-1)$} & $0.399 * * *$ & 0.572 *** & 0.207 & $0.282 * * *$ \\
\hline & $(0.0992)$ & $(0.0584)$ & $(0.141)$ & $(0.0802)$ \\
\hline \multirow{3}{*}{ es } & $-0.410 *$ & $-1.098^{*}$ & $-4.748^{* *}$ & $-7.236^{* *}$ \\
\hline & $(0.246)$ & $(0.562)$ & $(1.885)$ & $(3.457)$ \\
\hline & & $-0.666^{*}$ & & -3.980 \\
\hline $\mathrm{bm}$ & & $(0.400)$ & & $(2.488)$ \\
\hline \multirow[b]{2}{*}{ es*bm } & & $0.156 *$ & & $0.950 *$ \\
\hline & & $(0.0922)$ & & $(0.574)$ \\
\hline \multirow{2}{*}{ Constant } & 1.24 & $4.460 *$ & $21.43^{* * *}$ & $29.78^{* *}$ \\
\hline & $(0.984)$ & $(2.426)$ & $(7.872)$ & $(15.01)$ \\
\hline Observations & 941 & 941 & 946 & 946 \\
\hline Number of groups & 258 & 258 & 258 & 258 \\
\hline Number of instruments & 46 & 74 & 31 & 60 \\
\hline AR1 & 0.000 & 0.000 & 0.006 & 0.000 \\
\hline AR2 & 0.110 & 0.338 & 0.585 & 0.368 \\
\hline Hansen & 0.599 & 0.231 & 0.560 & 0.223 \\
\hline
\end{tabular}

Note: The estimation of GMM uses xtabond2 in STATA 14. Standard errors in parentheses, ${ }^{* * *} p<0.01,{ }^{* *} p<0.05,{ }^{*} p<0.1$.

\section{Discussion}

According to the analysis, environmental and social disclosure has a detrimental effect on firm performance. The interaction between information disclosure and board meetings demonstrates a positive and significant effect on firm performance, consistent with the agency theory. According to the agency theory, a board monitoring role will alleviate agency conflicts, increase investor returns, and improve financial performance. In other words, the interaction between board meetings is positive; as a result, the relationship between ES and firm performance is strengthened. This study made the following recommendations to improve further listed companies' sustainability efforts based on the findings. First, firms should recognise the value of non-financial information to shareholders when investing responsibly and factoring environmental and social factors into investment decisions. Second, firms should consider environmental issues and community needs when conducting business activities, as these factors increasingly affect the business value of firms. Third, the authority must compel all publicly traded companies to disclose their CSR practices. Additionally, NGOs and civil society will assist businesses in improving their CSR programmes.

Overall, these findings will assist policymakers, the economic sector, and investors in enhancing potential CSR programmes and inspiring firms to become more involved in CSR activities. This study believes the findings will encourage more effective responsible investment approaches and capital deployment towards a more sustainable future. This study identifies the interaction between the board meeting and information disclosure that is useful to policymakers, researchers, and businesses since its findings provide additional new knowledge in information disclosure literature. The analysis shows that when the board meeting increases, information disclosure is significant to firm performance. This study indicates that information disclosure alone is not capable of increasing firm performance.

\section{Conclusions}

This study provides valuable guidance to publicly traded companies by demonstrating that firms participating in environmental and social reporting and holding effective board meetings will see significant improvements in financial performance the following 
reporting year. Information transparency will be beneficial in ensuring increased competitiveness, allowing the company to use an alternative approach or plan to generate enormous profits and increase shareholder value. The findings of this study indicate that board meetings encourage management to strive towards investors gains and performance enhancement. The findings are supported by the agency theory in which board monitoring is important to reduce the agency problem and maximise the shareholders' returns.

The results of the interaction between information disclosure and board meeting show a positive and significant impact on firm performance, and the agency theory supports it. The agency theory suggests that the board monitoring role will reduce agency conflict, increase investors' returns, and boost financial performance. In other words, this study shows that information disclosure with effective board monitoring is positively linked to firm success.

The study's limitation is that the sample size was small due to Bloomberg's data score not being available. As a result, the findings may not accurately reflect the sample of Malaysian listed companies disclosing sustainability information. Future research may modify industry productivity disparities, considering the difference between an individual firm's profitability and the industry average. By comparing a company's performance to that of its industry competitors (benchmarking), we can gain insight into how it performs compared to other companies in its industry. Given that some businesses are more productive than others, examining how the relationship between profitability and sustainability varies by sector may be instructive. Another suggestion for future research is to include other corporate governance interactions, such as board size and CEO duality, as a mechanism for ensuring sustainability report assurance.

Author Contributions: Conceptualization, N.A.Y. and N.A.H.; methodology, N.A.Y.; software, N.A.Y.; validation, N.A.Y. and N.A.H.; formal analysis, N.A.Y.; investigation, N.A.Y.; resources, N.A.Y.; data curation, N.A.Y.; writing-original draft preparation, N.A.Y.; writing-review and editing, N.A.Y.; visualization, N.A.Y.; supervision, N.A.Y.; project administration, N.A.Y. and N.A.H.; funding acquisition, N.A.Y. Both authors have read and agreed to the published version of the manuscript.

Funding: This research received no external funding.

Conflicts of Interest: The authors declare no conflict of interest.

\section{References}

Al Farooque, Omar, Wonlop Buachoom, and Lan Sun. 2020. Board, audit committee, ownership and financial performance-Emerging trends from Thailand. Pacific Accounting Review 32: 54-81. [CrossRef]

Allegrini, Marco, and Giulio Greco. 2013. Corporate boards, audit committees and voluntary disclosure: Evidence from Italian listed companies. Journal of Management and Governance 17: 187-216. [CrossRef]

Amin, Aminul, Niki Lukviarman, Djoko Suhardjanto, and Erna Setiany. 2018. Audit committee characteristics and audit-earnings quality: Empirical evidence of the company with concentrated ownership. Review of Integrative Business and Economics Research 7: 18-33.

Arellano, Manuel, and Stephen Bond. 1991. Some Tests of Specification for Panel Data: Monte Carlo Evidence and an Application to Employment Equations. The Review of Economic Studies 58: 277. [CrossRef]

Atan, Ruhaya, Fatin Adilah Razali, Jamaliah Said, and Saunah Zainun. 2016. Environmental, Social and Governance (ESG) disclosure and its effect on firm's performance: A comparative study. International Journal of Economics and Management 10: 355-75.

Azar, Adel, FaribaHabibi Rad, and Botyari Ehsan. 2014. Board characteristics and firm performance in Malaysia. Journal of Research in Business and Management 2: 28-34.

Botosan, Christine A. 1997. Disclosure of level and the cost equity capital. The Accounting Review 72: 323-49.

Buachoom, Wonlop. 2018. How do board structures of Thai firms influence different quantile levels of firm performance? Advances in Pacific Basin Business, Economics and Finance 157-89. [CrossRef]

Bursa Malaysia Berhad. 2017. Corporate Governance Guide Executive Summary, 3rd ed. Kuala Lumpur: Bursa Malaysia Berhad.

Che Hat, Mohd Hassan, Rashidah Abdul Rahman, and Sakthi Mahenthiran. 2008. Corporate governance, transparency and performance of Malaysian companies. Managerial Auditing Journal 23: 744-78. [CrossRef]

Chen, L., A. Feldmann, and O. Tang. 2015. The relationship between disclosures of corporate social performance and financial performance: Evidences from GRI reports in manufacturing industry. International Journal of Production Economics 170: 445-456. [CrossRef] 
Chou, Hsin-I., Huimin Chung, and Xiangkang Yin. 2013. Attendance of board meetings and company performance: Evidence from Taiwan. Journal of Banking and Finance 37: 4157-71. [CrossRef]

Chung, Huimin, William Q. Judge, and Yi-Hua Li. 2015. Voluntary disclosure, excess executive compensation, and firm value. Journal of Corporate Finance 32: 64-90. [CrossRef]

Cooke, Terry E. 1989. Voluntary corporate disclosure by Swedish companies. Journal of International Financial Management E Accounting 1: 171-95.

Correia, Thamirys de Sousa, and Wenner Glaucio Lopes Lucena. 2020. Board of directors and code of business ethics of Brazilian companies. RAUSP Management Journal 55: 263-79.

Donnelly, Ray, and Mark Mulcahy. 2008. Board structure, ownership, and voluntary disclosure in Ireland. Corporate Governance: The International Journal of Business in Society 16: 416-29. [CrossRef]

Elamer, Ahmed A., Aws AlHares, Collins G. Ntim, and Ismail Benyazid. 2018. The corporate governance-risk-taking nexus: Evidence from insurance companies. International Journal of Ethics and Systems 34: 493-509. [CrossRef]

Fama, Eugene F. 1970. Efficient capital markets: A review of theory and empirical Work. The Journal of Finance 25: 383-417. [CrossRef]

Gackowski, Tomasz. 2017. The idea of investor relations in the modern economy: A communication approach. Economic ResearchEkonomska Istrazivanja 30: 1-13. [CrossRef]

Ghani, Erlane K., Nurazrin Tarmezi, Jamaliah Said, and Yuliansyah Yuliansyah. 2016. The effect of risk management and operational information disclosure practices on public listed firms' financial performance. International Journal of Economics and Management 10: 235-52.

Han, Seung Hun, Minhee Kim, Duk Hee Lee, and Sangwon Lee. 2014. Information asymmetry, corporate governance, and shareholder wealth: Evidence from unfaithful disclosures of Korean listed firms. Asia-Pacific Journal of Financial Studies 43: 690-720. [CrossRef]

Hanh, Le Thi My, Irene Wei Kiong Ting, Qian Long Kweh, and Lam Thi Hoang Hoanh. 2018. Board meeting frequency and financial performance: A case of listed firms in Vietnam. International Journal of Business and Society 19: 464-72.

Hansen, Lars Peter, and Kenneth J. Singleton. 1982. Generalized instrumental variables estimation of nonlinear rational expectations models. Econometrica 50: 1269-86. [CrossRef]

Hashim, Mohd Hafiz, Anuar Nawawi, and Ahmad Saiful Azlin Puteh Salin. 2014. Determinants of strategic information disclosureMalaysian evidence. International Journal of Business and Society 15: 547-72.

Hussain, Nazim, Ugo Rigoni, and René P. Orij. 2018. Corporate governance and sustainability performance: Analysis of triple bottom line performance. Journal of Business Ethics 149: 411-32. [CrossRef]

Jensen, Michael C. 1993. The modern industrial revolution, exit and the failure of internal control systems. The Journal of Finance 48: 831-80. [CrossRef]

Jensen, Michael C., and William H. Meckling. 1976. Theory of the firm: Managerial behavior, agency costs and ownership structure. Journal of Financial Economics 3: 305-60. [CrossRef]

Kasbun, Nur Fatin, Boon Heng Teh, and Tze San Ong. 2016. Sustainability Reporting and Financial Performance of Malaysian Public Listed Companies. Institutions and Economics 8: 78-93.

Kowalewski, Oskar. 2016. Corporate governance and corporate performance: Financial crisis (2008). Management Research Review 39: 1494-515. [CrossRef]

Loh, Lawrence, Nguyen Thi Phuong Thao, Isabel Sim, Thomas Thomas, and Wang Yu. 2016. Sustainability reporting in Asean: No. October. Singapore: Asean CSR Network and Centre for Governance, Institutions Organisations, NUS Business School.

Maina, Edward Kandiru, Hazel Gachunga, Willy Muturi, and Martin Ogutu. 2017. Influence of firm characteristics on the impact of disclosure and transparency in the performance of companies listed in Nairobi Securities Exchange. International Journal of Scientific Research and Management 5: 6994-7007. [CrossRef]

Merton, Robert C. 1986. A simple model of capital market equilibrium with incomplete information. Journal of Finance 42: 483-510. [CrossRef]

Mishra, Rakesh Kumar, and Sheeba Kapil. 2018. Effect of board characteristics on firm value: Evidence from India. South Asian Journal of Business Studies 7: 41-72. [CrossRef]

Nguyen, Thi H. H., Mohamed H. Elmagrhi, Collins G. Ntim, and Yue Wu. 2021. Environmental performance, sustainability, governance and financial performance: Evidence from heavily polluting industries in China. Business Strategy and the Environment 1-19. [CrossRef]

Norraidah, Abu Hasan, and Yakob Noor Azuddin. 2018. Symmetrical Information Disclosure for Investors' Investment Decisions. International Journal of Engineering E Technology 7: 397-99.

Nurulyasmin, Ju Ahmad, Afzalur Rashid, and Jeff Gow. 2017. Board meeting frequency and corporate social responsibility (CSR) reporting: Evidence from Malaysia. Corporate Board: Role, Duties and Composition 13: 87-99.

Paul, Jyoti. 2017. Board activity and firm performance. Indian Journal of Corporate Governance 10: 44-57. [CrossRef]

Preston, Lee E., and Douglas P. O'bannon. 1997. The corporate social-financial performance relationship Reproduced with permission of the copyright owner: Further reproduction prohibited without permission. Business E Society 36: 419-29.

Rahman, Rashidah Abdul, and Roszaini Mohd Haniffa. 2005. The effect of role duality on corporate performance. Corporate Ownership $\mathcal{E}$ Control 2: 40-47. 
Vafeas, Nikos, and Elena Theodorou. 1998. The relationship between board structure and firm performance in the UK. British Accounting Review 30: 383-407. [CrossRef]

Wang, Yan, Kaleemullah Abbasi, Bola Babajide, and Kemi C. Yekini. 2020. Corporate governance mechanisms and firm performance: Evidence from the emerging market following the revised CG code. Corporate Governance (Bingley) 20: 158-74. [CrossRef] 